\title{
Transcriptome of oil palm (Elaeis guineensis Jacq.) roots treated with Ganoderma boninense
}

\begin{abstract}
Basal stem rot (BSR) is the most devastating disease of oil palm. In this study, we examined the transcriptional responses of oil palm roots treated with a causal agent of BSR, Ganoderma boninense using a cDNA microarray approach. A total of 61 from 3,748 transcripts examined were found to be significantly up- or down-regulated in oil palm roots infected with G. boninense at 3 and 6 weeks post inoculation compared to those from uninfected roots. The differentially expressed genes identified in the artificially infected oil palm roots included genes encoding isoflavone reductase, Em protein H2, SPX domain-containing protein 1, pathogenesis-related protein 1, vicilin-like antimicrobial peptide. The gene expression of isoflavone reductase, which is involved in the production of phytoalexin and three related genes in the phenylpropanoid biosynthetic pathway was also profiled in the treated oil palms using real-time quantitative reverse transcription PCR. This information has contributed to our understanding of the defense mechanisms of oil palm in response to $\mathrm{G}$. boninense, the future development of molecular markers for marker assisted breeding and screening of oil palms that are tolerant to G. boninense.
\end{abstract}

Keyword: cDNA microarray; Expression profiles; Ganoderma boninense; Oil palm; Phytoalexin 